\title{
IMPLEMENTASI QAWAID FIQHIYYAH DALAM EKONOMI DAN INDUSTRI KEUANGAN SYARIAH
}

\author{
Irwan Maulana $^{1}$ \\ irwangravity@gmail.com
}

\begin{abstract}
The existence of Islamic Principles of Jurisprudences (qawa'id fiqhiyyah) is to provide a more practical guide derived from the original text, namely al-Qur'an and alHadith to the community. With this, some theologians (ulama) can prepare life guidelines for Muslims in different spheres from time to time and place to place. As is known, Islam gives its people the opportunity through those who have the authority to carry out ijtihad in various ways guided by the Messenger of Allah, through ijma', qiyas, istihsan, istishab, istislah (masalihul-mursalah) and so on to look for truth that has not been explained in detail in the Qur'an and the Hadith of the Muhammad SAW. Likewise, in economic life, or in the treasury of the works of earlier fuqaha commonly called muamalah, the use of qawa'id fiqhiyyah becomes very important.

"All forms of muamalah are basically changed (permissible) unless there is a argument that forbids it". This qaidah is the main qaidah in every halal of all forms of economic and financial transactions unless there is a reason for the sharia prohibition. There are at least five qa'idah-hakyyah known as al-Asasiyyatul-Khamsah which in its application ulama classify qawa'id into six different fields, namely mahdhah (special) worship, ahwal as-Syahshiyyah (personal and family matters), you 'amalah maaliyah (economic transactions), jinayah (criminality), siyasah (politics), and fiqh qadhaya (procedural law and justice). The purpose of this paper is to find out how the implementation or implementation of qawaid fiqhiyyah in the sharia economy and financial industry.
\end{abstract}

\section{Keywords: Islamic Principles of Jurisprudences; Muamalah; Islamic Economics}

\begin{abstract}
Abstrak
Keberadaan qawa'id fiqhiyyah adalah untuk menyediakan panduan yang lebih praktis yang diturunkan dari nash asalnya yaitu al-Qur'an dan al-Hadits kepada masyarakat. Dengan qawa'id fiqhiyyah ini para ulama dan fuqaha dapat menyiapkan garis panduan hidup bagi umat Islam dalam lingkup yang berbeda dari waktu ke waktu dan tempat ke tempat. Sebagaimana diketahui Islam memberi kesempatan kepada umatnya melalui mereka yang memiliki otoritas yaitu para ulama untuk melakukan ijtihad dengan
\end{abstract}

\footnotetext{
${ }^{1}$ Dosen Tetap Prodi Perbankan Syariah STAI Asy-Syukriyyah
} 
berbagai cara yang dituntunkan oleh Rasulullah, melalui ijma', qiyas, istihsan, istishab, istislah (masalihul-mursalah) dan sebagainya untuk mencari kebenaran yang belum dijelaskan secara rinci dalam al-Qur'an maupun Hadits Rasulullah SAW. Demikian pula, dalam kehidupan ekonomi, atau yang dalam khazanah karya para fuqaha terdahulu biasa disebut muamalat, pemakaian qawa'id fiqhiyyah menjadi sesuatu yang amat penting.

"Segala bentuk muamalah pada dasarnya adalah mubah (boleh) kecuali ada dalil yang mengharamkannya". Qaidah ini menjadi qaidah utama pada setiap kehalalan segala bentuk transaksi ekonomi dan keuangan kecuali apabila ada alasan syar'I yang melarangnya. Setidaknya ada lima qa'idah asasiyyah yang dikenal dengan al-AsasiyyatulKhamsah yang dalam penerapannya ulama mengklasifikasikan qawa'id kedalam enam bidang berbeda, yaitu ibadah mahdhah (khusus), ahwal as-Syahshiyyah (hal-ikhwal pribadi dan keluarga), mu'amalah maaliyah (transaksi ekonomi), jinayah (kriminalitas), siyasah (politik), dan fiqh qadhaya (hukum acara dan peradilan). Adapun tujuan paper ini untuk mengetahui bagaimana penerapan atau implentasi qawaid fiqhiyyah dalam ekonomi dan industri keuangan syariah.

\section{Kata Kunci: Qawaid Fiqhiyyah; Muamalah; Ekonomi Syariah}

\section{A. Pendahuluan}

Sebagai landasan aktifitas umat Islam sehari-hari dalam upaya memahami maksudmaksud ajaran Islam (maqasid Syariah) secara lebih menyeluruh, keberadaan Qawa'id fiqhiyyah menjadi sesuatu yang amat penting, termasuk dalam kehidupan berekonomi. Baik di mata para ahli ushul (ushuliyyun) maupun para ahli fiqh (fuqaha), pemahaman terhadap qawa'id fiqhiyyah adalah mutlak diperlukan untuk melakukan suatu "ijtihad" atau pembaharuan pemikiran dalam masalah muamalat atau lebih khas lagi ekonomi.

Manfaat keberadaan qawa'id fiqhiyyah adalah untuk menyediakan panduan yang lebih praktis yang diturunkan dari nash asalnya yaitu al-Qur'an dan al-Hadits kepada masyarakat. Maqasid Syariah diturunkan kepada manusia untuk memberi kemudahan dalam pencapaian kebutuhan ekonomi, yang dapat dikategorikan menjadi tiga yaitu menjaga dan memelihara kepentingan primer atau Dharuriyyat (basic necessities) yang biasa didefinisikan oleh para ulama dengan 5 (lima) elemen cakupan yaitu: agama, jiwa, akal, keturunan dan kekayaan.

Kedua, memenuhi kebutuhan sekunder atau Haajiyat yaitu kebutuhan-kebutuhan seperti kendaraan dan sebagainya sebagai fasilitas hidup manusia dan terakhir mencapai kebutuhan tersier atau Tahsiniyat untuk melengkapi kebutuhan manusia dalam hal memperindah kehidupan dengan sedikit kemewahan secara tidak berlebihan. 


\section{Jurnal Asy-Syukriyyah}

Dengan qawa'id fiqhiyyah ini para ulama dan fuqaha dapat menyiapkan garis panduan hidup bagi umat Islam dalam lingkup yang berbeda dari waktu ke waktu dan tempat ke tempat. Sebagaimana diketahui Islam memberi kesempatan kepada ummatnya melalui mereka yang memiliki otoritas yaitu para ulama untuk melakukan ijtihad dengan berbagai cara yang dituntunkan oleh Rasulullah, melalui ijma', qiyas, istihsan, istishab, istislah (masalihul- mursalah) dan sebagainya untuk mencari kebenaran yang belum dijelaskan secara rinci dalam al-Qur'an maupun Hadits Rasulullah SAW. Demikian pula, dalam kehidupan ekonomi, atau yang dalam khazanah karya para fuqaha terdahulu biasa disebut muamalat, pemakaian qawa'id fiqhiyyah menjadi sesuatu yang amat penting.

Ratusan atau bahkan mungkin ribuan qawa'id telah dirumuskan oleh para fuqaha dari kalangan empat madzhab. Ash-Shiddieqie (1981) memandang qa'idah sebagai sebuah perangkat yang cukup penting sebagai panduan untuk menurunkan kaidah yang memerlukan pembuktian. Para fuqaha terdahulu menyusun qawa'id dalam suatu panduan yang disebut al-Asybah wan-Nazhaair. Istilah ini dipakai pertama kali oleh Khalifah Umar bin Khaththab ketika menunjuk Abu Musa al-'Asy' ari menjadi Qadhi di Bashra, dengan menyatakan "Fahami tentang penampakan dan kemiripan suatu masalah (alAsybah wan-Nazhaair), kemudian tetapkan qiyas untuk masalah yang serupa." Para fuqaha sepakat bahwa proses pemahaman dan penurunan qawa'id ini sama dengan proses yang dilakukan oleh para usuliyyun dalam menurunkan panduan hukum berupa Qawa'id al-Usuliyyah berdasarkan metode qiyas.

Terdapat sejumlah qawa'id fiqhiyyah yang dirumuskan oleh para ulama/fuqaha, sebagai bagian dari fatwa mereka, yang menyinggung persoalan perilaku ekonomi umat Islam. Sebagai contoh: 'al-aadah muhakkamah atau kebiasaan dapat menjadi dasar hukum. Dalam suatu masyarakat, dimana transaksi jual beli dalam skala kecil biasa dilakukan tanpa harus menyebutkan 'aqadnya, maka apabila antara penjual dan pembeli sudah saling memahami akan terjadinya transaksi tersebut, sebagaimana kebiasaan pada masyarakat yang bersangkutan, maka proses transaksi yang memberi kemudahan tersebut dianggap sah untuk mengetahui besarnya kontribusi para fuqaha terdahulu dalam menyusun qawa'id fiqhiyyah dan juga mengetahui kontribusi dan mengukur relevansi qawa'id fiqhiyyah dalam pemikiran dan perilaku ekonomi umat. 


\section{B. Tinjauan Pustaka}

\section{Pengetian Qawaid}

Dalam Dictionary of Modern Written Arabic, karya Milton Cowan (ed) kata qa'idah (قاعدة) atau jama'nya qawa'id (قواعد) secara literal berarti: asas, landasan, dasar, basis atau fondasi suatu bangunan atau ajaran agama dan sebagainya. Dalam pengertian yang lebih khas, qa'idah dapat juga bermakna ajaran, garis panduan, formula, pola atau metode. Qa'idah memiliki makna yang sama dengan 'asas' atau 'prinsip' yang mendasari suatu bangunan, agama atau yang semisalnya (al-Nadwi, 1991).

Dari sisi pengertian menurut ilmu fiqh, Nadwi (1991) dan juga al-Jurjani (Djazuli, 2006) mendefinisikan qai'dah sebagai aturan umum atau universal (kuliyyah) yang dapat diterapkan untuk semua yang bersifat khusus atau bagian-bagiannya (juz'iyyah). Sedang dalam pandangan para fuqaha yang lain qa'idah adalah aturan umum yang mencakup sebagian besar (aghlabiyyah) dari bagian-bagiannya (Nadwi). Mukhtar dkk (1995) menyimpulkan qa'idah sebagai aturan umum yang diturunkan dari hukum-hukum furu' yang sejenis dan jumlahnya cukup banyak.

Berdasarkan penelitian terhadap kitab- kitab dan riwayat hidup para penyusunnya, aturan fiqih dalam bentuk qa'idah ini dapat tersusun melalui suatu proses yang panjang dan tidak terbentuk sekaligus sebagai sebuah bangunan pengetahuan (body of knowledge) tentang qa'idah sekaligus, melainkan secara bertahap (Jazuli, 2006). Menurut Jazuli, sebelum al-Karkhi dari madzhab Hanafi, sebelum- nya telah ada pengumpulan qa'idah, namun tampaknya tidak tersusun menjadi karya sistematis, oleh seorang ulama madzhab Hanafi lainnya, yaitu Abu Thahir ad-Dibasi hidup diakhir abad ke 3 Hijriyah sampai dengan awal abad ke empat. Sebanyak 17 qa'idah telah disusun oleh ad-Dibasi, yang kemudian juga disampaikan kepada seorang ulama madzhab as-Syafii yaitu Abu Sa'id alHarawi. Dari sumber ad-Dibasi, al-Karkhi mengembangkannya lebih lanjut menjadi 36 qa'idah (an-Nadwi, 1997) atau 37 qa'idah (Jazuli). 


\section{Jurnal Asy-Syukriyyah}

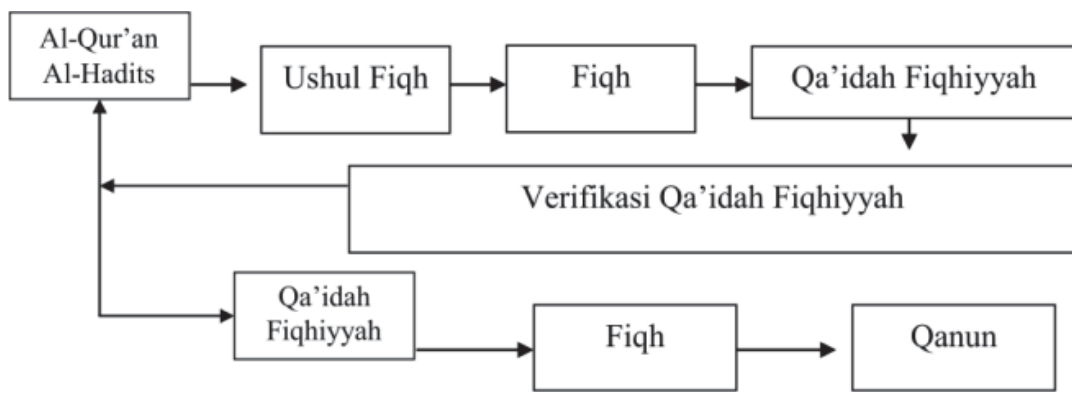

Qawa'id disusun berdasarkan materi-materi fiqh, untuk selanjutnya diverifikasi untuk mendapatkan hasil qawa'id yang lebih sempurna, untuk kemudian tersusun kembali fiqh sebagai kelengkapan dari khazanah fiqh yang telah ada, kemudian ketentuanketentuan hukumnya menjadi hasil akhir dari proses tersebut.

\section{Qawaid Fiqhiyyah Al-Khamsah (Al-Asasiyyah)}

Proses penerapan aturan syar'i dalam qa'idah menurut Mahmassani (1980) sama dengan penerapan metodologi qiyas dalam memilih aturan yang tepat dalam ushul fiqh. Apabila aturan rinci sebagaimana dijumpai pada al-Asybah wan-Nazhair muncul dari kasus yang serupa, maka qa'idah dengan sendirinya dapat diterapkan. Nadwi (1991) dan Mahmassani berpendapat bahwa tulisan tentang qawa'id fiqhiyyah tersusun sejak mulai abad ke delapan Hijriyah, melalui karya Ibnul Wakil as-Syafi'i (716 H), Tajuddin as-Subki $(771 \mathrm{H})$, Ibnul Mulaqqin $(804 \mathrm{H})$, dan yang lebih monumental lagi karya Jalaluddin asSuyuti $(911 \mathrm{H})$. Satu karya yang juga tak kalah pentingnya adalah berasal dari madzhab Hanafi yaitu karya Ibnu Nujaim $(970 \mathrm{H})$.

Dalam ketiga kitab al-Asybah wan-Nazhair karya Tajuddin as-Subki, Jalaluddin as-Suyuti maupun Ibnu Nujaim $(970 \mathrm{H})$, pembedaan antara qa'idah umum atau asas dengan qa'idah khusus atau rinci (detail) dijelaskan secara memadai. As-Subki dan asSuyuti merumuskan Lima qa'idah asasiyyah yang dikenal dengan al-AsasiyyatulKhamsah, yang kemudian disusun dalam al-Majallah al-ahkam al-adliyyah sebagai kompilasi hukum syariah pertama di Dunia yang dikeluarkan pada jaman pemerintahan Turki Usmani, yaitu: 


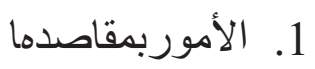

"Segala sesuatu tergantung kepada maksudnya (niat)".

$$
\text { 2. اليقين لا يز ال بالثكك }
$$

"Keyakinan tidak dapat dihapus oleh keragu-raguan".

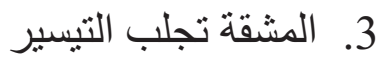

"Setiap bentuk Kesulitan akan mendatangkan kemudahan".

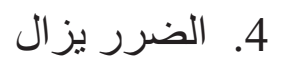

"Setiap bentuk kemudharatan itu harus dihilangkan".

$$
\text { 5. العادة محكمة }
$$

"Adat kebiasaan dapat menjadi sumber hukum".

Dalam penerapannya, Jazuli mengklasifikasikan qawa'id kedalam enam bidang berbeda, yaitu ibadah mahdhah (khusus), ahwal as-Syahshiyyah (hal-ikhwal pribadi dan keluarga), mu'amalah maaliyah (transaksi ekonomi), jinayah (kriminalitas), siyasah (politik), dan fiqh qadhaya (hukum acara dan peradilan).

\section{Implementasi Qawaid Fiqhiyyah Dalam Ekonomi dan Keuangan Syariah Qawaid Fiqhiyyah Dharurat Pada Kasus-Kasus Industri Keuangan}

Beberapa qa'idah fiqhiyyah memberi ruang kepada pemikiran ataupun praktekpraktek ekonomi, sebagaimana yang juga diklasifikasikan oleh Jazuli (2006). Dalam karyanya, al-Fiqh al-Islam fi Tsaubihi at-Tajdid, terbitan tahun 1963, Muhammad Mustafa az-Zarqa, sebagaimana dikutip oleh Jazuli (2006), menyebutkan setidaknya terdapat 25 qawa'id yang terkait dengan transaksi mu'amalah dan seiring dengan perkembangan jaman, keperluan adanya kaidah yang lebih banyak, nampaknya tidak dapat dihindarkan.

Di antara qawa'id yang paling mendasar dalam masalah ini adalah

$$
\text { الآصل في المعاملة الابا حة حتى يدل الدليل على تحريمها }
$$

"Segala bentuk muamalah pada dasarnya adalah mubah (boleh) kecuali ada dalil yang mengharamkannya".

Qaidah ini menjadi qaidah utama pada setiap kehalalan segala bentuk transaksi ekonomi dan keuangan kecuali apabila ada alasan syar'i yang melarangnya. 


\section{Jurnal Asy-Syukriyyah}

Adapun diantara contoh kasus aplikasi qaidah darurat pada industri financial yaitu penerapan dual banking system pada bank sentral Negara kita, kemudian penerapan perbankan syariah dengan sistem Unit Usaha Syariah (UUS) dimana pelayanan syariahnya hanya dengan menggunakan window system pada kantor-kantor bank konvensional. Qawaid fiqhiyyah tentang darurat pada kasus-kasus financial diatas diambil dari qaidah asasiyyah nomor 3, dimana qaidah-qaidah furu'iyyah-nya adalah sebagai berikut :

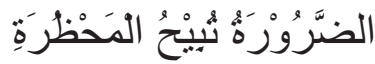

"Dalam keadaan darurat membolehkan yang mudarat (dilarang)".

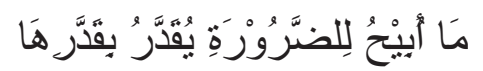

"Apa-apa yang dibolehkan karena mudarat diperkirakan sewajarnya, atau menurut batasan ukuran kebutuhan minimal".

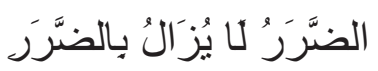

Kemudaratan tidak dapat dihilangkan dengan kemudaratan yang lain”." “

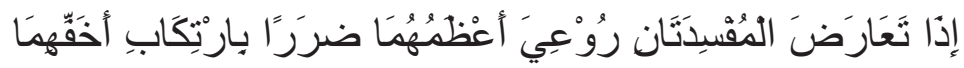

"Jika ada dua kemudaratan yang bertentangan, diambil kemudaratan yang paling kecil".

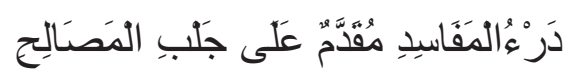

"Menolak kemafasadatan didahulukan daripada mengambil kemaslahatan".

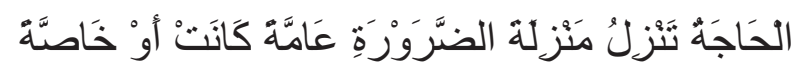

"Kebutuhan itu (kadangkala) terkontaminasi dengan kemudaratan, baik secara umum maupun khusus".

\section{Qawaid Gharar Pada Industri Financial}

Banyak terdapat penelitian pada praktek keuangan syariah di Indonesia yang dalam hasilnya terdapat banyak aspek yang kurang dalam pemenuhan akad-akad syariah, yang diantaranya adalah praktek letter of credit pada sektor ekspor - impor dimana posisi perbankan syariah sebagai wakil dalam akad wakalah sekaligus sebagai kafil dalam akad kafalah yang kemudian akan berhubungan langsung dengan perbankan konvensional yang berada di luar negeri dengan menggunakan unsur interest dalam transaksinya. Perihal praktek ini terdapat gharar dari sisi external yang berada diluar kuasa perbankan syariah di 
Indonesia, yang kemudian (dalam prakteknya) tereliminasi dengan qaidah-qaidah fiqh sebagai berikut :

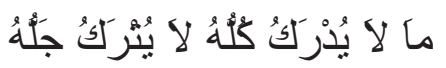

"Apa yang tidak bisa diraih semuanya, tidak boleh ditinggalkan semuanya"

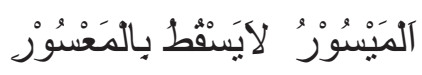

"Perkara yang mudah (bisa dikerjakan) tidak bisa dianggap gugur kewajibannya karena adanya perkara yang sulit (tidak bisa dikerjakan)”.

\section{Qawaid Fiqhiyyah Pada Perbankan Dan Keuangan Islam Kontemporer}

a) Qawaid Fiqh Tentang Denda atas Keterlambatan Cicilan

Sanksi yang dikenakan lembaga keuangan syariah (LKS) kepada nasabah yang mampu membayar, tetapi menunda-nunda pembayaran dengan disengaja, sementara nasabah yang tidak/belum mampu membayar disebabkan force majeur tidak boleh dikenakan sanksi. Hal tersebut terdapat dalam fatwa Dewan Syariah Nasional NO: 17/DSN-MUI/IX/2000) melalui kaidah berikut:

$$
\text { الآصل في المعاملة الابا حة حتى يدل الدليل على تحريمها }
$$

"Segala bentuk muamalah pada dasarnya adalah mubah (boleh) kecuali ada dalil yang mengharamkannya".

$$
\text { لاضِرَرَ وَلاضِرِرَارَ. }
$$

"Tidak boleh membahayakan diri sendiri dan tidak boleh pula membahayakan orang lain".

Sanksi didasarkan pada prinsip ta'zir, yaitu bertujuan agar nasabah lebih disiplin dalam melaksanakan kewajibannya. Sanksi dapat berupa denda sejumlah uang yang besarnya ditentukan atas dasar kesepakatan dan dibuat saat akad ditandatangani. Dana yang berasal dari denda diperuntukkan sebagai dana sosial.

b) Qawaid Fiqh Tentang Resiko, Biaya dan Keuntungan (Hasil)

Sudah menjadi sunnatullah adanya resiko (rugi), biaya dan keuntungan dalam suatu kegiatan usaha. 
"Resiko/biaya yang ditanggung sejalan dengan keuntungan yang diperoleh".

الخر اج بالضمان

"Keuntungan/ profit yang diperoleh sejalan dengan resiko yang ditanggung" (H.R. Abu Daud).

c) Qawaid Fiqh tentang kebebasan berkontrak, mengadakan perjanjian dan berakad.

Hadits Nabi riwayat Tirmidzi dari 'Amr bin 'Auf al-Muzani:

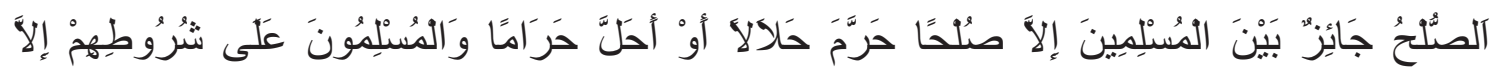

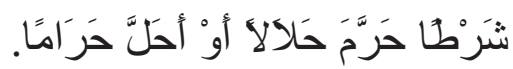

"Perjanjian boleh dilakukan di antara kaum muslimin kecuali perjanjian yang mengharamkan yang halal atau menghalalkan yang haram; dan kaum muslimin terikat dengan syarat-syarat mereka kecuali syarat yang mengharamkan yang halal atau menghalalkan yang haram”.

d) Qawaid Fiqh gharar yang sedikit dan yang banyak

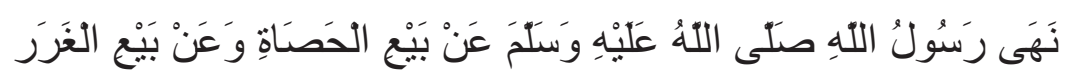

"Rasulullah Saw melarang jual beli al-hashah dan jual beli gharar".

e) Qawaid Fiqh tentang Hybrid Contract

Aliudin Za'tary dalam bukuFiqh Muamalah Al-Maliyah alMuqaran mengatakan "Tidak ada larangan dalam syariah tentang penggabungan dua akad dalam satu transaksi, baik akad pertukaran (bisnis) maupun akad tabarru'. Hal ini berdasarkan keumuman dalil-dalil yang memerintahkan untuk memenuhi (wafa) syaratsyarat dan akad-akad"

Mayoritas ulama Hanafiyah, sebagian pendapat ulama Malikiyah, ulama Syafi'iyah, dan Hanbali berpendapat bahwa hukum hybrid contract adalah sah dan diperbolehkan menurut syariat Islam. Ulama yang membolehkan beralasan bahwa hukum asal dari akad adalah boleh dan sah, tidak diharamkan dan dibatalkan selama tidak ada dalil hukum yang mengharamkan atau membatalkannya. (Al-'Imrâni, Al-'uqûd al-Mâliyah al-Murakkabah, hal. 69). Kecuali menggabungkan dua akad yang menimbulkan riba atau menyerupai riba, seperti menggabungkan qardh dengan akad yang lain, karena adanya 
larangan hadits menggabungkan jual beli dan qardh. Demikian pula menggabungkan jual beli cicilan dan jual beli cash dalam satu transaksi

Menurut Ibn Taimiyah, hukum asal dari segala muamalat di dunia adalah boleh kecuali yang diharamkan Allah dan Rasulnya, tiada yang haram kecuali yang diharamkan Allah, dan tidak ada agama kecuali yang disyariatkan.( Ibn Taimiyah, Jâmi' al-Rasâil, j. 2, hal. 317)

Nazih Hammad dalam buku al-'Uqûd al-Murakkabah fi al-Fiqh alIslâmy menuliskan, "Hukum dasar dalam syara' adalah bolehnya melakukan transaksi hybrid contract, selama setiap akad yang membangunnya ketika dilakukan sendiri-sendiri hukumnya boleh dan tidak ada dalil yang melarangnya. Ketika ada dalil yang melarang, maka dalil itu tidak diberlakukan secara umum, tetapi mengecualikan pada kasus yang diharamkan menurut dalil itu. Karena itu, kasus itu dikatakan sebagai pengecualian atas kaidah umum yang berlaku yaitu mengenai kebebasan melakukan akad dan menjalankan perjanjian yang telah disepakati. (Nazîh Hammâd, al-'uqûd alMurakkabah fi al-Fiqh al-Islâmy, hal. 8)

Demikian pula dengan Ibn al-Qayyim, ia berpendapat bahwa hukum asal dari akad dan syarat adalah sah, kecuali yang dibatalkan atau dilarang oleh agama.(Ibn alQayyim, I'lâm al-Muwaqqi'în, j. 1, hal. 344)

Al-Syâtiby menjelaskan perbedaan antara hukum asal dari ibadat dan muamalat. Menurutnya, hukum asal dari ibadat adalah melaksanakan (ta'abbud) apa yang diperintahkan dan tidak melakukan penafsiran hukum. Sedangkan hukum asal dari muamalat adalah mendasarkan substansinya bukan terletak pada praktiknya (iltifât ila ma'âny). Dalam hal ibadah tidak bisa dilakukan penemuan atau perubahan atas apa yang telah ditentukan, sementara dalam bidang muamalat terbuka lebar kesempatan untuk melakukan perubahan dan penemuan yang baru, karena prinsip dasarnya adalah diperbolehkan (al-idzn) bukan melaksanakan (ta'abbud).[1] ( Al-Syâtiby, al-Muwâfaqât, j. 1, hal. 284)

Adapun jenis-jenis hybrid contract adalah sebagai berikut, Pertama, Multi Akad yang mukhtalithah (bercampur) yang memunculkan nama baru, seperti bay' istighlal , bay' tawarruq, musyarakah mutanaqishah dan bay wafa'. 
Kedua Hybrid Contract yang mujtami'ah/mukhtalitah dengan nama akad baru, tetapi menyebut nama akad yang lama, seperti sewa beli (bay' at-takjiry) Lease and purchase. Contoh lain ialah mudharabah musytarakah pada life insurance dan deposito bank syariah.

Ketiga Hybrid contract, yang akad-akadnya tidak bercampur dan tidak melahirkan nama akad baru. tetapi nama akad dasarnya tetap ada dan eksis dan dipraktekkan dalam suatu transaksi. Contohnya :

1) Kontrak akad pembiayaan take over pada alternatif 1 dan 4 pada fatwa DSN MUI No $31 / 2000$

2) Kafalah wal ijarah pada kartu kredit,

3) Wa'ad untuk wakalah murabahah, ijarah, musyarakah, dll pada pembiayaan rekening koran or line facility

4) Murabahah wal wakalah pd pembiayaan murabahah basithah.

5) Wakalah bil ujrah pada L/C, RTGS, General Insurance, Factoring,

6) Kafalah wal Ijarah pada LC, Bank Garansi, pembiayaan multi jasa / multi guna, kartu kredit.

7) Mudharabah wal murabahah/ijarah/istisna pada pembiayaan terhadap karyawan koperasi instansi.

8) Hiwalah bil Ujrah pada factoring.

9) Rahn wal ijarah pada REPO SBI dan SBSN

10) Qardh, Rahn dan Ijarah pada produk gadai emas di bank syariah.

Keempat, Hybrid Contract yang mutanaqidhah (akad-akadnya berlawanan). Bentuk ini dilarang dalam syariah. Contohnya menggabungkan akad jual beli dan pinjaman (bay' wa salaf). Contoh lain, menggabungkan qardh wal ijarah dalam satu akad. Kedua contoh tersebut dilarang oleh nash (dalil) syariah, yaitu hadits Rasulullah Saw. Contoh lainnya : menggabungkan qardh dengan janji hadiah

\section{Qawaid Fiqhiyyah Tentang Ekonomi Makro}

Agama Islam adalah agama yang sangat paripurna yang memerhatikan seluruh aspek kehidupan manusia baik dalam aspek ibadah maupun muamalah. Diantara yang diperhatikannya adalah dalam sektor muamalah maaliyah ataupun iqtishod secara makro, karenanya ia merupakan bagian yang tidak terpisahkan (integral) dari agama Islam. Islam 
memandang aktifitas ekonomi secara positif. Semakin banyak manusia terlibat dalam aktivitas ekonomi maka semakin baik, sepanjang tujuan dari prosesnya sesuai dengan ajaran Islam. Ketaqwaan kepada Tuhan tidak berimplikasi pada penurunan produktivitas ekonomi, sebaliknya justru membawa seseorang untuk lebih produktif. Kekayaan dapat mendekatkan kepada Tuhan selama diperoleh dengan cara-cara yang sesuai dengan nilainilai Islam. dimana aspek maslahat dipandang sebagai aspek yang harus selalu dijunjung tinggi sebagaimana tujuan dalam maqashid syariah. Dalam kaitan tersebut, Islam juga sangat menghormati kegiatan ekonomi, yang termasuk di dalamnya adalah mengenai mekanisme pasar. Sampai-sampai Rasulullah melarang adanya inervensi terhadap pasar dan harga, karena intervensi tersebut hanya akan menimbulkan ketidak seimbangan pada pasar yang nantinya dikhawatirkan akan menyebabkan kerugian bagi penjual dan pembeli. Sebagaimana Rasulullah bersabda :

عن أنس رضي الله عنه قال :غلا السعر على عهد رسول الله صلى الله عليه وسلم فقال: الناس يا رسول الله غلا السعر فسعر لنا، فقال رسول الله صلى الله عليه وسلم: إن الله هو المسعر القابض الباسط الرازق، و إني لأرجو أن ألقى الله وليس أحد منكم يطلبني في دم ولا مال .رواه الخمسه إلا النسائي وصححه ابن حبان وقال أبو عيسى الترمذي :حديث حسن صحيح.

Berdasarkan hadist diatas, sesungguhnya melakukan intervensi harga dilarang dalam Islam. Namun apabila dibawa kedalam skup yang lebih luas lagi secara makro, maka intervensi pemerintah dibolehkan didalam prakteknya mengingat kekhawatiran diantaranya yaitu, untuk menjauhkan pelaku-pelaku spekulan dalam praktek monopolistik komoditas tertentu dengan melakukan ihtikar, dan juga agar daya beli masyarakat tidak menurun serta kekhawatiran akan bahaya kelaparan yang berujung kepada kebinasaan. Disini para ulama berijtihad untuk memperbolehkan praktek intervensi harga dengan tujuan menegakkan kemaslahatan dengan qaidah :

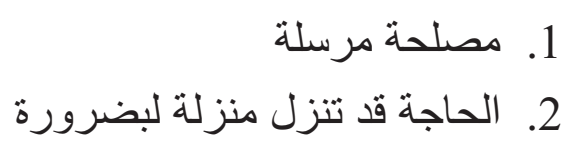




\section{Jurnal Asy-Syukriyyah}

\section{Kesimpulan}

Terdapat sejumlah qawa'id fiqhiyyah yang dirumuskan oleh para ulama/fuqaha, sebagai bagian dari fatwa mereka, yang menyinggung persoalan perilaku ekonomi umat Islam.

Qawa'id dikodifikasi berdasarkan materi-materi fiqh, untuk selanjutnya diverifikasi untuk mendapatkan hasil qawa'id yang lebih sempurna, untuk kemudian tersusun kembali fiqh sebagai kelengkapan dari khazanah fiqh yang telah ada, kemudian ketentuanketentuan hukumnya menjadi hasil akhir dari proses tersebut.

As-Subki dan as-Suyuti merumuskan Lima qa'idah asasiyyah yang dikenal dengan al-Asasiyyatul-Khamsah, yang kemudian disusun dalam al-Majallah al-ahkam al-adliyyah sebagai kompilasi hukum syariah pertama di Dunia yang dikeluarkan pada jaman pemerintahan Turki Usmani.

Dalam penerapannya, Jazuli mengklasifikasikan qawa'id kedalam enam bidang berbeda, yaitu ibadah mahdhah (khusus), ahwal as-Syahshiyyah (hal-ikhwal pribadi dan keluarga), mu'amalah maaliyah (transaksi ekonomi), jinayah (kriminalitas), siyasah (politik), dan figh qadhaya (hukum acara dan peradilan).

Beberapa qa'idah fiqhiyyah memberi ruang kepada pemikiran dan Implementasinya kedalam ekonomi dan keuangan syariah, Muhammad Mustafa az-Zarqa, sebagaimana dikutip oleh Jazuli (2006), menyebutkan setidaknya terdapat 25 qawa'id yang terkait dengan transaksi mu'amalah. Seiring perkembangan jaman, keperluan adanya kaidah yang lebih banyak, nampaknya tidak dapat dihindarkan.

Di antara qawa'id yang paling mendasar dalam masalah ini adalah

$$
\text { الآصل في المعاملة الابا حة حتى يدل الدليل على تحريمها }
$$

"Segala bentuk muamalah pada dasarnya adalah mubah (boleh) kecuali ada dalil yang mengharamkannya". 


\section{DAFTAR PUSTAKA}

Alwani, Taha Jabir al-. 1994. Source Methodology in Islamic Jurispruden'e: Usul al- Fiqh al-Islami, Revised English Ed. By Yusuf Talal DeLorenzo and Anas S. Al- ShaikhAli. Herndon. Virginia: Interna- tional Institute of Islami' Thought. 1415.

Djazuli, H.A. 2006. Kaidah-kaidah Fikih: Kaidah-kaidah Hukum Islam dalam Menyelesaikan Masalah-masalah Praktis. Jakarta: Kencana Prenada Media Group.

Fatwa Dewan Syariah Nasional, Majelis Ulama Indonesia.

Kamali, Muhammad, Hashim. 1989. Principles of Islamic Jurisprudence. Petaling Jaya. Malaysia: Pelanduk Publication (M) Sdn Bhd.

Mahmassani, Sobhi. 1980. Falsafah al-Tashri fi al-Islam. English Translation by Farhat J. Ziadeh, The Original Arabic. Beirut. Dar al-ilm li al-Malayin. Shah Alam, Malaysia: Penerbitan Hizbi.

Mu'htar, Kamal, dkk. 1995. Ushul Fikh (Jilid 1). Yogyakarta: Dana Bakti Wakaf.

Nadwi, Ali, Ahmad, al-. 1412H/1991. Al- qawa id al-fiqhiyyah: Mafhumuha, Nash- atuha, Tatawwuruha, Dirasatu Mu- allafatiha, Adallatuha, Muhimmatuha, Tatbiqatuha. Dar al-Qalam.. Damascus

Rahman, Fazlur. 1965. Islamic Methodology in History. Karachi. Pakistan: Islamic Research Institute.

Shiddieqy, T.M. Hasbi, ash-. 1981. Pengantar Hukum Islam. Jakarta: Penerbit Bulan Bintang.

Syabir, Muhammad, Usman. 2000. Al-Qawa'id al-Kulliyyah wad-dhawabith alFiqhiyyah. Yordania: daarul-Furqaan.

Umar, Hasbi. 2014. Filsafat Fiqh Muamalat Kontemporer (Filosofi Dasar untuk Aksi). Jakarta: penerbit Rajawali Press.

Weeramantry, C.G. Islamic Jurisprudence: An International Perspective, Hampshire and London: The MacMillan Press Ltd. 